\title{
Testing the Validity Model for Measuring Customer Confidence Using (CFA)
}

\author{
Ridowan Mohamed Ahmed ${ }^{1}$, Dr. Fuadahbinti Johari ${ }^{2}$ \\ ${ }^{1,2}$ Faculty of Economics and Muamalat, UniversitiSains Islam Malaysia, Bandar BaruNilai, 71800 Nilai, Negeri Sembilan, Malaysia
}

\begin{abstract}
The current study aimed to test the validity of a proposed model for measuring customer confidence in the Islamic financial institutions in the Libya. The proposed model consisted of the dimensions and standards of the customer confidence evaluation based on the (Legitimate Supervision, Disclosure and transparency, Regulations and laws).and In order to achieve this, used (CFA) through the Amos program (Amos 21.0).The study population of customers of financial institutions consists of (Libyan Stock Market and the Bank of the Republic and the main branches). The findings of the study showed that the proposed model was valid for measuring customer confidence in the Islamic financial institutions in Libya.
\end{abstract}

Keywords: Legitimate Supervision, Disclosure and transparency, Regulations and laws

\section{Introduction}

Trust is defined as the individual's positive feelings towards another party in terms of his/her trust or confidence in that party in doing business and actions as agreed upon by the two parties. Researchers have focused on interpreting the concept of trust as the individual's degree of faith and acceptance of the decisions and policies formulated by the organization's management or administration which are implemented and managed fairly to all parties. However, in the previous literature of management, it seems that the difference in the definition of trust is commonplace. This is because of the different views of management researchers or authors as well as their different ideologies around this concept. For example, as defined by Gamson, trust is a possibility that enables the system of decisions to obtain desirable outcomes or results for the individual or even a group of people even if there is no influence exercised on this system. Rotteralso defined trust as the expectation held by an individual or a group of people holds which can be written or oral promises given by others (either individuals or groups) and which can be relied upon. Trust is also defined as a set of common expectations between two parties where the perceived agreement is viewed as a non-written psychological, rational and behavioral agreement on commitment between the two parties. This agreement representing such psychological commitment results in a relationship of mutual trust between the two parties that governs or controls the relationship between the two parties though it is not written and it is not legally binding but it is basically the only criterion in evaluating the quality and nature of the relationship between them (Ahmed Saudi, 2005). Hence, it can be said that trust is a particular party's expectations that make that party rely on another party to achieve desirable results or it is the organization's ability to accomplish offering a service to customers accurately as promised.

Due to the much attention of marketing research to the element of trust, trust has become an important marketing variable that plays a role in building the relationship between the institution and consumers. There are trends that have focused on the explanatory variables or variables that explain trust because of its importance for marketers in gaining consumer trust. In this regard, there are several factors that explain trust. These factors are linked or related to the institution, the agent, the consumer, and other factors are associated with the brand (Benmiled,2012). Moreover, trust plays an important role in taking decisions regarding purchase, thus making the customer's exchange of relationship with the partner or the other party longer and last forever. It is also considered the key element in the success of commercial relations, particularly those characterized by a high degree of risk where trust be considered as a safety net. Since it is not possible to evaluate the products before the actual consumption, trust becomes a valuable decision factor. Therefore, many researchers have established scales to measure trust, the most important of which is the one that is based on the credibility, integrity, and good reception (Halliburton, 2010). However, this study focused on the factors associated with the organization or institution in designing a measure of customers' trust factor.

\section{Research Objectives}

The current study aimed to testing a proposed model for measuring customer confidence in the Islamic financial institutions in Libya.

\section{Method}

\subsection{Research Instruments}

In this regard, it is relied upon the questionnaire as a tool to gather the necessary information for this study as one of the most suitable scientific research tools that achieve the survey study objectives and to obtain information and facts associated with a determined reality, for achieving the study, a questionnaire is made for the purposes of processing the studying test the validity of a proposed model for measuring customer confidence.

\subsection{Confirmatory Factor Analysis}

The Structural Equation Modeling (AMOS) model-fitting program is used to test the validity constructs are to test the validity of a proposed model for measuring customer

\section{Volume 5 Issue 6, June 2016}




\section{International Journal of Science and Research (IJSR) \\ ISSN (Online): 2319-7064 \\ Index Copernicus Value (2013): 6.14 | Impact Factor (2015): 6.391}

confidence. The overall model fit is assessed by using four indices of the model goodness-of-fit: (1) the chi-square statistics; (2) the minimum value of the discrepancy between the observed data and the hypothesized model divided by degrees of freedom (CMIN/DF) or normed chisquare (Marsh \& Hocevar,1985)described that the minimum fit function for (CMIN/DF) of an acceptable fit is less than (5); (3) the comparative fit index (CFI) greater than(0.90) (McDonald \& Marsh,1990);(4) in addition (RMSEA) less than (0.08) (Mac Callum et al, 1996).

\subsection{Construct Validity}

The employment of factor loading composite reliability (CR) and average variance extracted (AVE) were proposed by (Hair, et al,2006) to determine the convergent validity if it equals to or greater than $(0.5)$, and the composite reliability equals to or greater than $(0.7)$, if were recommended by (Hair et al,2006). In addition (AVE) reading values should be greater than (0.5), and greater than (Shared Variance-SV).

\section{Results}

\subsection{The Modified Model}

From Figure (1) that shows the results of the (Confirmatory Factor Analysis-CFA) for the proposed model for measuring customer confidence, it is evident that the model is free of the illogical correlation since it reaches or exceeds the integer (1). This also indicates that there is not any problems in the Confirmatory Factor Analysis (CFA) used for testing the validity of this model that comprises three factors: The first factor containing the Legitimate Supervision, the second factor including theDisclosure and transparency, and the third factor including the Regulations and laws. As seen in Figure (1) and Table (1), the indicators of agreement between the model and the data exceeded the (T-value), thus, implying that there is disagreement between modelcustomer confidenceand the data of the sample since the value of the (Chi-Square) was (1057.738) and the degree of freedom was (186), and the level of significance was $(\mathrm{P}=0.000)$. In addition, we can see that the normative (Chi-Square) (Chi-Square /degrees of freedom) was (5.687) Greater than (5), and the value of relative strength index (CFI) was (0.830) less than (0.90). The results also show that the value of the index (RMSEA) was (0.111) Greater than $(0.080)$. Due to this contradiction between the model and the data, it was necessary to modify the customer confidence model in this study.

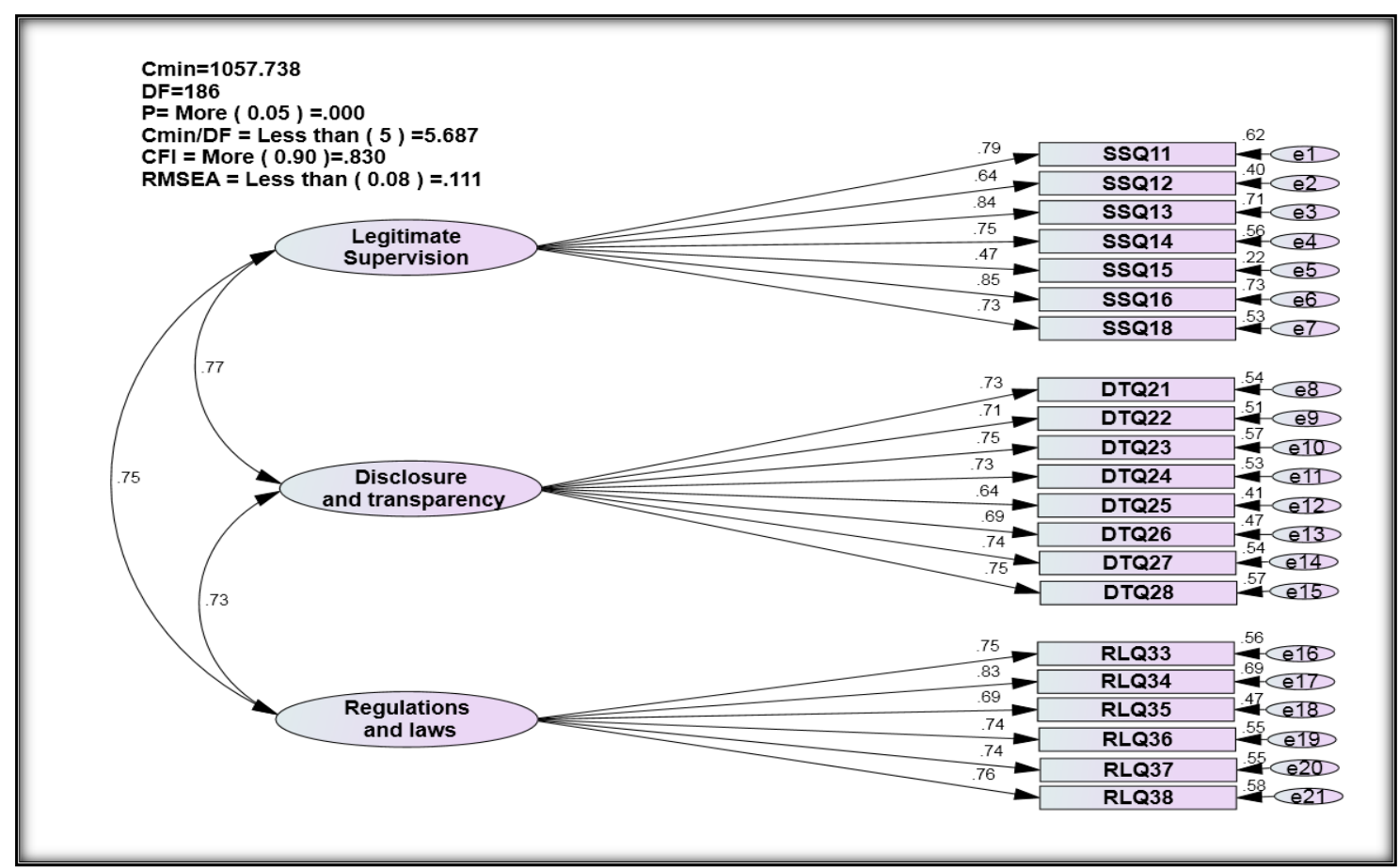

Figure 1: Model customer confidence before the amendment

In order to modify this model, we followed was deleting (SSQ12, SSQ15) Because it was less loading of the other item at the same factor(Legitimate Supervision), in addition to linking item (SSQ11) with item (SSQ16) it was shown in Figure (2), and deleting (DTQ22, DTQ25, DTQ26, DTQ27) where the ratio of saturation or loading this item was the least compared to other items at the same factor(Disclosure and transparency), in addition deleting (RLQ36,RLQ37) Because it was less loading of the other item at the same factor(Regulations and laws).
Table 1: index value of customer confidence model before and after modification

\begin{tabular}{|c|c|c|c|}
\hline $\begin{array}{c}\text { indicators } \\
\text { consistency }\end{array}$ & $\begin{array}{c}\text { index value before } \\
\text { modification }\end{array}$ & $\begin{array}{c}\text { index value after } \\
\text { modification }\end{array}$ & $\begin{array}{c}\text { Function value on } \\
\text { the quality of } \\
\text { conformity }\end{array}$ \\
\hline $\mathrm{Cmin}$ & 1057.738 & 201.982 & --- \\
\hline $\mathrm{df}$ & 186 & 61 & --- \\
\hline $\mathrm{P}$ & 0.000 & 0.000 & Non \\
\hline $\mathrm{Cmin} / \mathrm{Df}$ & 5.687 & 3.311 & Less than $(5)$ \\
\hline $\mathrm{CFI}$ & 0.830 & 0.953 & More $(0.90)$ \\
\hline $\mathrm{Rmsea}$ & 0.111 & 0.078 & Less than $(0.08)$ \\
\hline
\end{tabular}

Volume 5 Issue 6, June 2016 www.ijsr.net 


\section{International Journal of Science and Research (IJSR) \\ ISSN (Online): 2319-7064}

Index Copernicus Value (2013): 6.14 | Impact Factor (2015): 6.391

\subsection{Confirmatory Factor Analysis of the customer confidence model}

The results of the goodness-of-fit of the final revised of the Customer confidence model showed that normed chi- square (CMIN/DF) was (3.311) the (Comparative Fit IndexCFI) was (0.953) and (RMSEA)was (0.078). Figure (2) shows the adequacy of the final revised of the Customer confidence model.

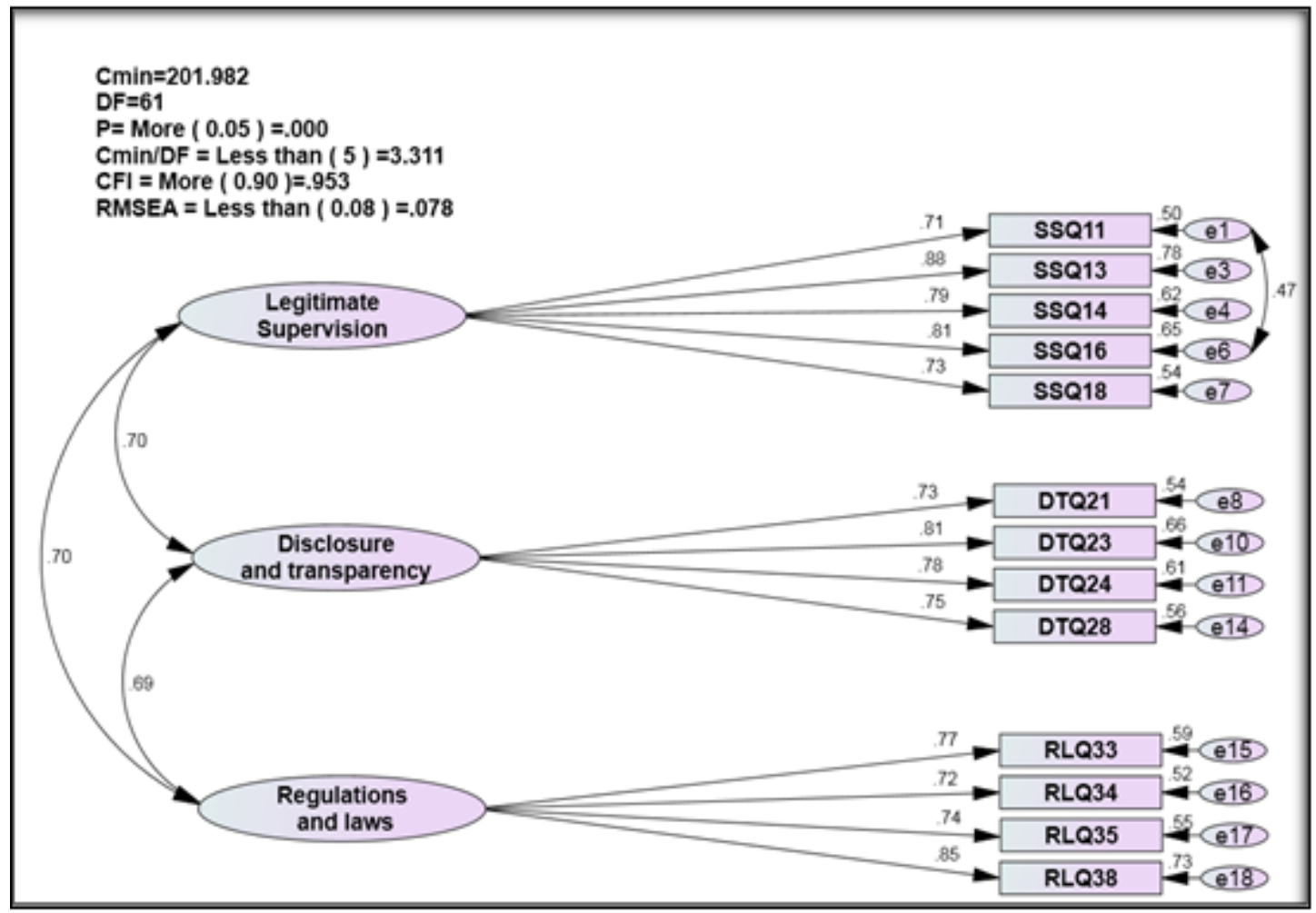

Figure 2: Customer confidence model after amendment.

\subsection{Construct Validity and Reliability}

In this study, the factor lodging for the parameters ranged from (0.71 to 0.88$)$, with all parameters were above $(0.5)$. The reliability ranged from (0.93 to0.94), were greater than (0.7). Furthermore, the (Average Variance ExtractedAVE) readings was $(0.61,0.59,0.59)$ where the value was greater than (0.5) and greater than (Shared Variance-SV) readings was $(0.49,0.49,0.47)$. Thus, all results fulfilled the (AVE), and The reliability discriminant validity of the model. Generally, the measurement model of the Customer confidence model was fit and fulfilled the construct as depicted in table (2) and (3).
Table 2: Shared Variance and Average Variance Extracted Between variables

\begin{tabular}{|c|c|c|c|}
\hline Variables & $\begin{array}{c}\text { Legitimate } \\
\text { Supervision }\end{array}$ & $\begin{array}{c}\text { Disclosure and } \\
\text { transparency }\end{array}$ & $\begin{array}{c}\text { Regulations } \\
\text { and laws }\end{array}$ \\
\hline $\begin{array}{c}\text { Legitimate } \\
\text { Supervision }\end{array}$ & $\underline{0.61}$ & $\underline{0.59}$ & \\
\hline $\begin{array}{c}\text { Disclosure and } \\
\text { transparency }\end{array}$ & 0.49 & 0.47 & $\underline{0.59}$ \\
\hline $\begin{array}{c}\text { Regulations and } \\
\text { laws }\end{array}$ & 0.49 & \multicolumn{2}{|l}{} \\
\hline
\end{tabular}




\section{International Journal of Science and Research (IJSR) \\ ISSN (Online): 2319-7064}

Index Copernicus Value (2013): 6.14 | Impact Factor (2015): 6.391

Table 3: Construct Validity and Reliability of customer confidence model

\begin{tabular}{|c|c|c|c|c|c|c|c|c|c|c|}
\hline $\begin{array}{l}\text { Item } \\
\text { code }\end{array}$ & variables & Items & Reliability & estimate & S. E. & C. $R$. & $P$ & Loading & $R$ & $A V E$ \\
\hline $\begin{array}{c}\text { SS } \\
\text { Q11 }\end{array}$ & \multirow{5}{*}{$\begin{array}{l}\text { Legitimate } \\
\text { Supervision }\end{array}$} & $\begin{array}{l}\text { When there is a legitimate guidance for financial } \\
\text { transactions in the financial institutions, do you } \\
\text { reassure of your financial transactions with the } \\
\text { institution }\end{array}$ & 0.91 & 0.894 & 0.056 & 15.752 & 0.000 & 0.71 & 0.50 & 0.61 \\
\hline $\begin{array}{r}\mathrm{SS} \\
\mathrm{Q} 13\end{array}$ & & $\begin{array}{c}\text { Does the verification of the availability of } \\
\text { legitimate supervision, internal control and } \\
\text { existence of an effective system of information } \\
\text { make you feel confident }\end{array}$ & 0.91 & 1.000 & - & - & - & 0.88 & 0.78 & - \\
\hline $\begin{array}{r}\mathrm{SS} \\
\mathrm{Q} 14\end{array}$ & & $\begin{array}{c}\text { Do you feel reassured when the safety of } \\
\text { depositors' and investors' money and maintenance } \\
\text { of it from the illegal use are available }\end{array}$ & 0.92 & 0.918 & 0.049 & 18.653 & 0.000 & 0.79 & 0.62 & - \\
\hline $\begin{array}{r}\mathrm{SS} \\
\mathrm{Q} 16\end{array}$ & & $\begin{array}{c}\text { When there the legitimate supervision for fatwa } \\
\text { and the implementation of such legitimate fatwa } \\
\text { are available, does this help you in dealing with } \\
\text { the institution }\end{array}$ & 0.91 & 0.974 & 0.050 & 19.424 & 0.000 & 0.81 & 0.65 & - \\
\hline $\begin{array}{r}\mathrm{SS} \\
\mathrm{Q} 18\end{array}$ & & $\begin{array}{c}\text { The Board of legitimate supervision should have } \\
\text { at least three members who meet all legitimate, } \\
\text { banking and legal ingredients }\end{array}$ & 0.92 & 0.901 & 0.053 & 16.730 & 0.000 & 0.73 & 0.54 & - \\
\hline $\begin{array}{l}\text { DT } \\
\text { Q21 }\end{array}$ & \multirow{4}{*}{$\begin{array}{l}\text { Disclosure and } \\
\text { transparency }\end{array}$} & $\begin{array}{c}\text { Is there a high degree of credibility for the } \\
\text { advertisements issued by the Islamic financial } \\
\text { institutions }\end{array}$ & 0.91 & 0.849 & 0.056 & 14.945 & 0.000 & 0.73 & 0.54 & 0.59 \\
\hline $\begin{array}{c}\text { DT } \\
\text { Q23 }\end{array}$ & & $\begin{array}{c}\text { Do you feel comfortable and reassured when you } \\
\text { get or obtain long-term and short-term loans }\end{array}$ & 0.92 & 1.000 & - & - & - & 0.81 & 0.66 & - \\
\hline $\begin{array}{c}\text { DT } \\
\text { Q24 }\end{array}$ & & $\begin{array}{l}\text { Is there an easy access to the financial statements } \\
\text { of the financial institutions }\end{array}$ & 0.91 & 0.938 & 0.058 & 16.037 & 0.000 & 0.78 & 0.61 & - \\
\hline $\begin{array}{c}\text { DT } \\
\text { Q28 }\end{array}$ & & $\begin{array}{l}\text { Islamic financial institutions follow a clear policy } \\
\text { in developing the current Islamic products }\end{array}$ & 0.91 & 0.894 & 0.061 & 15.354 & 0.000 & 0.75 & 0.56 & - \\
\hline $\begin{array}{l}\text { RL } \\
\text { Q33 }\end{array}$ & \multirow{4}{*}{$\begin{array}{l}\text { Regulations and } \\
\text { laws }\end{array}$} & $\begin{array}{c}\text { Does the legal system in the Libyan environment } \\
\text { represent a burden or an obstacle for the } \\
\text { performance of financial institutions }\end{array}$ & 0.92 & 0.886 & 0.053 & 16.738 & 0.000 & 0.77 & 0.59 & 0.59 \\
\hline $\begin{array}{c}\text { RL } \\
\text { Q34 }\end{array}$ & & $\begin{array}{c}\text { Is there a need for the Libyan legislators to amend } \\
\text { legislation that conforms to the nature of the } \\
\text { Islamic financial institutions }\end{array}$ & 0.92 & 0.821 & 0.053 & 15.396 & 0.000 & 0.72 & 0.52 & - \\
\hline $\begin{array}{l}\text { RL } \\
\text { Q35 }\end{array}$ & & $\begin{array}{c}\text { Is the legislation one of the important factors in } \\
\text { the success or failure of a project }\end{array}$ & 0.91 & 0.838 & 0.052 & 15.950 & 0.000 & 0.74 & 0.55 & - \\
\hline $\begin{array}{c}\text { RL } \\
\text { Q38 }\end{array}$ & & $\begin{array}{c}\text { Is there a legal environment that contributes to the } \\
\text { success of the Islamic financial institutions }\end{array}$ & 0.91 & 1.000 & - & - & - & 0.85 & 0.73 & - \\
\hline
\end{tabular}

\section{Conclusion}

The current study aimed to test the validity of a proposed model for measuring customer confidence in the Islamic financial institutions in Libya. The proposed model included customer confidence as a potential variable that is realized through several apparent factors that are the dimensions and standards of the customer confidence evaluation based on the (Legitimate Supervision, Disclosure and transparency, Regulations and laws). To achieve this research aim, the researcher carried out a (Confirmatory Factor Analysis-CFA) by using the Amos program (Amos 21.0). This was test the validity of the model that can be used for measuring the degree and level of customer confidence. Based on the results of the analysis and the outputs of the Amos in Figure (1) and Table (1), it is evident that there is disagreement between the customer confidencemodel and the data, which emphasizes the need to modify the model. After the model modification as illustrated by Figure (2) and Table (3), there was a match between the model and the sample data based on the goodness of fit indices. Moreover, the (Average Variance Extracted-AVE) of all the factors was higher than the standard test factors (0.50)and greater than (Shared Variance-SV)as Table (2). Therefore, it can be concluded that the proposed model in this study has both convergent and discriminate validity, which implies that the model is valid and reliable to be used for measuring of customer confidence.

\section{References}

[1] Hair, J. F., Anderson, R. E., Tatham, R. L. \& Black, W. C. (2006). Multivariate Data Analysis (5th ed.), New Jersey, Prentice-Hall.

[2] .MacCallum, R. C., Browne, M. W., \& Sugawara, H. M. (1996). Power Analysis and Determination of Sample

[3].Marsh, H. W., \& Hocevar, D. (1985). Application of confirmatory factor analysis to the study of self-concept: First-and higher order factor models and their invariance across groups. "Psychological bulletin", 97(3), 562-582. http://dx.doi.org/10.1037/0033-2909.97.3.562

[4] .McDonald, R. P., \& Marsh, H. W. (1990). Choosing a multivariate model: Noncentrality and goodness of fit. "Psychological Bulletin", 107(2), 247-255. 